\title{
Hauras jaetTu TOImijuUs ammatillisessa KUNTOUTUKSESSA
}

\author{
Leena Åkerblad: YTT, tutkijatobtori, Jyväskylän yliopisto \\ Kaisa Haapakoski: YTT, tutkijatobtori, Jvwäskylän yliopisto
}

leena.akerblad@jyu.fi; kaisa.haapakoski@jyu.fi

Janus vol. 28 (3) 2020, 220-236

\section{¿ J a I U \&}

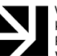

Tiivistelmä

Yhteistoiminta ja asiakaskeskeisyys ovat ammatillisen kuntoutuksen keskeisiä elementtejä. Niihin voi liittyä jaettua toimijuutta, joka sisältää kuulluksi ja ymmärretyksi tulemisen kokemuksia ja yhteisiin päämääriin sitoutumista. Tässä artikkelissa tarkastelemme jaettua toimijuutta haurastuttavia toiminta- ja puhetapoja ammatillisen kuntoutuksen yhteistoiminnassa. Aineisto kerättiin osana Kelan ammatillista kuntoutusselvitystä koskevaa arviointitutkimusta, ja se sisälsi eri osapuolten haastatteluja ja avoimia kyselyvastauksia. Temaattisessa analyysissa kiinnitimme huomiomme jaetun toimijuuden kannalta keskeisiin yhteistoiminnan prosesseihin. Suunnittelun ja päätöksenteon prosesseissa jaettua toimijuutta haurastuttivat jännitteiset ja jäykät toimintatavat. Niihin liittyi neuvotteluasemien epätasa-arvoisuutta, palvelun kehyksen ja kuntoutustyön arjen välisiä jännitteitä sekä ajallista epätahtisuutta. Sitoutumisen, vastuun ja tuen prosesseissa aktiivista, yksilöllistä toimijuutta korostavat ajattelutavat vaikeuttivat tuen jatkuvuuden tarpeen tunnistamista ja järjestelmien vastuunottoa.

\section{JOHDANTO}

Kuntoutuksessa on meneillään siirtymä järjestelmä- ja asiantuntijakeskeisyydestä kohti asiakaskeskeisyyttä,ja asiakkaan rooli kuntoutuksen suunnittelussa ja päätöksenteossa on kasvanut (STM 2015). Asiakaskeskeisyyden toteutumista kuvastavat asiakkaiden kokemukset kuntoutusprosessin sujuvuudesta, kuulluksi tulemisesta, arvostavasta ja kunnioittavasta kohtelusta sekä kuntoutuksen vastaamisesta omiin tarpeisiin (ks. Jeglinsky ym. 2013; Leplege ym. 2007). Kuntoutus toteutuu aina erilaisissa suhteissa, ja siihen sisältyy runsaasti eri toimijoiden ja järjestelmien yhteistoimintaa (Harra 2014; Lindh 2013; Seppänen-Järvelä ym. 2015; Väyrynen \& Lindh 2013). Tämä yhteistoi- minta määrittää osaltaan kuntoutuksen koettua asiakaskeskeisyyttä.

Tämä artikkeli on syntynyt motivaatiosta selvittää laadullisen tutkimusotteen avulla niitä yhteistoimintaan liittyviä tekijöitä, jotka voivat selittää asiakaskeskeisyyden toteutumista tai toteutumisen ongelmia ammatillisen kuntoutuksen palveluissa. Tässä tutkimuksessa tarkastelemme jaettua toimijuutta haurastuttavia toiminta- ja ajattelutapoja ammatillisen kuntoutuksen yhteistoiminnassa. Analyysissa kiinnitämme huomiomme jaetun toimijuuden kannalta keskeisiin yhteistoiminnan prosesseihin: suunnitteluun ja päätöksentekoon sekä sitoutumiseen, vastuuseen ja tukeen. Ajattelemme, että jaetun toimijuuden käsite tarjoaa kuntoutuksen 
yhteistoiminnan ja asiakaskeskeisyyden tarkasteluun oman erityislaatuisen kulmansa. Jaetun ja yhteisen toimijuuden on myös nähty edistävän kuntoutuksen keskeistä päämäärää eli asiakkaan yksilöllisen toimijuuden vahvistumista (ks. Romakkaniemi \& Järvikoski 2012; Salminen ym. 2017). Artikkelin aineisto on koottu osana Kelan ammatillista kuntoutusselvitystä koskevaa arviointitutkimusta. Tutkimuksessa kävi ilmi, että asiakaskeskeisyys toteutui kuntoutuspalvelun käytännöissä ja sen muodostamassa institutionaalisessa järjestyksessä vaihtelevasti. Tämän järjestyksen sisällä palveluihin osallistuvat kokivat voimauttavia hetkiä ja kohtaamisia, mutta myös yksin ja kuulematta jäämistä. Yksin ja kuulematta jäämisen kokemukset olivat yhteydessä palvelun vähäisempään koettuun vaikuttavuuteen. (Åkerblad ym. 2018.)

Romakkaniemen ja kumppaneiden (2018, 63-72) mukaan kuntoutukseen kytkeytyy erilaisia ajattelu- ja toimintatapoja eli rationaliteetteja: kuntoutuksen käsitteellistämisiä, työkäytäntöjä ja toimintamalleja sekä toimijoilta odotettavia asemia ja kykyjä (ks. myös Lindh \& Lappi 2018). Tämä artikkeli perustuu oletukseen siitä, että tietyt ammatillisen kuntoutuksen ajattelu- ja toimintatavat saattavat vaikeuttaa jaetun toimijuuden rakentumista. Jakamatonta toimijuutta koskevissa tutkimuksissa on usein painotettu kokemusta siitä, ettei henkilö ole tullut kuulluksi, nähdyksi tai kohdatuksi (esim. Hokkanen 2012). Tässä artikkelissa syvennytään tarkemmin siihen, millaisiin ammatillisen kuntoutuksen toiminta- ja ajattelutapoihin kuvatun kaltainen kokemus kytkeytyy.
Aiemmassa tutkimuksessamme kuulematta jääminen ei paikantunut ainoastaan osallistuja-ammattilainen-vuorovaikutussuhteeseen, vaan ammatilliseen kuntoutukseen institutionaalisena järjestyksenä ja toimijoiden verkostona (ks. Åkerblad ym. 2018). Kuntoutuksen toimijat eivät ole ainoastaan yksilöitä, vaan myös organisaatioita, yhteisöjä ja järjestelmiä. Erilaiset professionaaliset, organisatoriset ja normatiiviset tekijät vaikuttavat myös yksittäisten kuntoutustyöntekijöiden toimintaan (Hokkanen 2012, 122). Sosiaalista kuntoutusta tarkastelleet Lappi ja Lindh $(2018,22)$ esittävät, että sosiaalinen kuntoutus voidaan tulkita asioiden ja toimijoiden välisiksi suhteiksi, jolloin sitä ei ymmärretä erilliseksi palveluksi, sektoriksi tai osaamisalueeksi. Tässä tutkimuksessa lähestytään ammatillista kuntoutusta samankaltaisesta näkökulmasta.

\section{JAETTU MONISELITTEINEN TOIMIJUUS}

Jaetun toimijuuden käsitettä on käytetty erityisesti "yhteistä toimintaa' käsittelevissä filosofisissa keskusteluissa (esim. Bratman 2009; Roth 2004). Näissä keskusteluissa on pohdittu kysymyksiä siitä, voidaanko jaettua toimijuutta ymmärtää yksilölliseen toimijuuteen liittyvien termien avulla (Roth 2017) ja mikä erottaa yksilöiden toiminnoista koostuvan jaetun toiminnan yksilöiden erillisistä, yksittäisistä teoista. Roth (2017) esittää, että jaetun toiminnan voidaan nähdä muodostuvan joko yksilöllisten intentioiden yhteensopivuuden tai niiden vuorovaikutuksellisen yhteisrakenteen avulla. Toisaalta on nähty, ettei jaetun toiminnan ydintä voida tavoittaa yksilöllisten intentioiden "summana". Esimerkiksi 
Schmidtin $(2008 ; 2014)$ yhteisiä intentioita painottavassa näkökulmassa on keskeistä ryhmämieli sekä siihen liittyvä pluraali itsetietoisuus ja toiminta.

Kuntoutuksen ja sosiaali- ja terveyspalvelujen kontekstissa jaetun toimijuuden käsitettä on hyödynnetty tarkasteltaessa mielenterveyspalveluiden käyttäjätyöntekijäsuhteita (Romakkaniemi \& Järvikoski 2012; 2013), palvelutaloasumista (Ruuskanen-Parrukoski 2018), vanhempien kokemuksia lasten kuntoutuksesta (Järvikoski ym. 2013) sekä palveluita koskevaa asiakastyytyväisyyttä (Hokkanen 2012). Näissä tutkimuksissa jaetun toimijuuden merkityksiä painotetaan hieman eri tavoin. Monissa kuitenkin nojataan Banduran (2001; 2000) ajatukseen siitä, että toimijuus ei ole koskaan pelkästään henkilökohtaista (personal agency). Se voi olla myös läheisen tai luotetun henkilön kanssa luotua yhteistä toimijuutta (proxy agen$c y$ ) tai yhteisöllistä toimijuutta (collective agency). Yhteinen ja yhteisöllinen toimijuus liittyvät Väyrysen ja Lindhin (2013, 407-408) mukaan perusteiltaan jaettuun toimijuuteen.

Yhteistoiminnalla on keskeinen rooli kuntoutuksessa (esim. Anderson ym. 2011; Harkki 2014), ja sen on nähty toimivan kuntoutuksen ja kuntoutumisen keskeisenä vaikutusmekanismina (Tuusa ym. 2018). Yhteistoiminnan lähikäsitteitä ovat muun muassa yhteistoimijuus, verkottuminen, kumppanuus, vuorovaikutus ja ennen kaikkea yhteistyö (Väyrynen \& Lindh 2013, 408). Tässä tutkimuksessa yhteistoiminnalla viitataan sekä ammattilaisen ja palveluihin osallistuvan asiakkaan yhdessä tekemiseen että laajempaan kuntoutuksen toimijoiden verkostoon. Analyyttisena käsitteenä yhteistoiminta mahdollistaa molemmat fokukset. Yhteistoimintaa ja jaettua toimijuutta ei kuitenkaan nähdä synonyymeinä. Analyysi perustuu ajatukselle siitä, että yhteistoimintaan voi erityisesti palveluihin osallistuvan asiakkaan näkökulmasta liittyä jaettua toimijuutta tai yhteistoiminta voi edistää jaettua toimijuutta, mutta ei väistämättä ja tietyillä ehdoilla.

Empiirisissä tutkimuksissa jaettua toimijuutta on usein tarkasteltu nimenomaan ammattilaisten ja asiakkaiden välisen suhteen kontekstissa. Tässä kontekstissa siihen on liitetty erilaisia määreitä ja ulottuvuuksia. Hokkasen (2012) mukaan jaetussa toimijuudessa asiakas ja ammattilainen jakavat vision asiakkaan avun tarpeista, heillä on yhteinen päämäärä ja he tekevät päätöksiä yhdessä. Romakkaniemen ja Järvikosken (2012) mukaan jaettu toimijuus on yhteistä työskentelyä kohti sitä, että palvelun käyttäjän hyvinvointi ja henkilökohtainen toimijuus vahvistuvat. Se sisältää jaettuja intentioita, vastavuoroista tiedonvaihtoa, kuulluksi ja arvostetuksi tulemisen kokemuksia, yhteistä päätöksentekoa sekä molemminpuolisia velvollisuuksia (Järvikoski ym. 2013). Hokkasen (2012) mukaan jaetun toimijuuden ehtona on kuulluksi tulemisen kokemus. Chang ja kumppanit (2010) puolestaan näkevät, että jaettu toimijuus perustuu yhteiseen suunnitteluun, päätöksentekoon ja sitoutumiseen sekä yhteiseen vastuuseen ja tukeen.

Tutkimuksissa on tarkasteltu myös jaetun toimijuuden haurastumista. Mielenterveyspalveluiden kontekstissa jaetun toimijuuden murentumista osoittivat toteutumattomat odotukset, hylkäämisen kokemukset sekä valta- 
konfliktit. Toteutumattomissa odotuksissa palvelut eivät kohdanneet odotuksia, hylkäämisen kokemuksissa asiakkaat tunsivat itsensä laiminlyödyiksi ja valtakonflikteissa ammattilaiset käyttivät valtaa ohittaen asiakkaiden omat toiveet. (Romakkaniemi \& Järvikoski 2012; 2013.) Nuoren ja vanhemman väliseen jakamattomaan toimijuuteen liittyi puolestaan tapa, jolla vanhemmat joko ottivat määräysvallan tai vetäytyivät kokonaan syrjään. Molemmissa tavoissa oli kyse hylkäämisen ja laiminlyönnin kokemuksista tai näkemysten ja toiveiden ylittämisestä. (Chang 2010.) Nuorten aikuisten sosiaalisessa kuntoutuksessa kohtaamattomuuden kokemukset liittyivät siihen, etteivät työntekijät paneutuneet osallistujien asiaan tai että tarjotut toimenpiteet tuntuivat epätarkoituksenmukaisilta. Lisäksi kohtaamattomuuden kokemus liittyi tapaamisten sattumanvaraisuuteen, tuen riittämättömyyteen, tiedottamisen puutteeseen ja kontrolliin. (Romakkaniemi ym. 2018, 98.)

Toimijuuden käsitteen käyttötavat ja -tarkoitukset vaihtelevat, ja käsite saattaa sisältää eri konteksteissa erilaisia odotuksia ja oletuksia. Kuntoutuksen toimenpiteisiin motivoitunut ja aktiivinen yksilöllinen toimijuus voidaan nähdä eräänlaisena ammatillisen kuntoutuksen ideaalina. Se sitoo ammatillisen kuntoutuksen myös aktiiviseen työvoima- ja sosiaalipolitiikkaan. "Aktiivisuus” käsitetään usein ulospäin havaittaviksi ja jopa mitattaviksi, tiettyyn päämäärään suuntaaviksi teoiksi. Ajatus autonomisesta, kykenevästä toimijasta voidaan kuitenkin kyseenalaistaa; toimijuus on aina tavalla tai toisella suhteellista (Ketokivi \& Meskus 2015). Toimijuus voi olla myös "pientä" tai "moniselitteistä", yhtä aikaa aktiivista ja passiivista, rationaalista ja ei-rationaalista (Honkasalo 2008; 2009; 2013, Honkasalo ym. 2014). Ajatus jaetusta toimijuudesta onkin osittain jännitteinen suhteessa kykenevän yksilöllisen toimijuuden ideaaliin.

Ammatilliseen kuntoutukseen osallistuvat kohtaavat työ- tai toimintakyvyn alenemista, sairauksia tai muita elämänkulkua hajottavia katkoksia. Tällaisissa tilanteissa toimijuuden säilyttäminen ja uudelleen rakentuminen edellyttää moninaista tukea (ks. Ketokivi 2009; Ketokivi \& Meskus 2015). Kelan ammatilliseen kuntoutusselvitykseen osallistuvien tilanteisiin saattaa liittyä esimerkiksi toimeentuloon liittyviä ongelmia, päällekkäisiä sairauksia ja pitkittynyttä työttömyyttä (Åkerblad ym. 2018). Näissä olosuhteissa toimijuuden rakentuminen saattaa edellyttää erityistä tukea. Kun ihmiset pyrkivät elämää mullistavissa tilanteissa tekemään valintoja ja harjoittamaan vapauttaan eli "toimijuuttaan", he turvaavat erilaisiin jatkuvuuden ja turvan tunnetta lisääviin tahoihin ja tekijöihin. (Ketokivi \& Meskus 2015).

\section{Aineisto JA Menetelmät}

Tutkimuksen aineisto kerättiin osana arviointi- ja toimeenpanotutkimusta (ks. Kela 2015a), jossa tarkasteltiin vuoden 2014 kuntoutuksen lakiuudistusta (Haapakoski ym. 2018) sekä Kelan ammatillista kuntoutusselvitystä (Åkerblad ym. 2018). Tutkimukset olivat osa Kelan Muutos-hanketta (ks. Kela 2015b). Tässä artikkelissa hyödynnetään ammatillista kuntoutusselvitystä koskevan tutkimuksen tapaustutkimuksellista haastatteluaineistoa sekä kahteen pos- 
tikyselyn avokysymykseen annettuja vastauksia.

Tapaustutkimuksellinen haastatteluaineisto kerättiin vuonna 2016. Kahdeksan palveluun osallistunutta asiakasta valittiin harkinnanvaraisena näytteenä niiden joukosta, jotka olivat antaneet postikyselyn yhteydessä alustavan suostumuksensa haastatteluun. Haastatteluun osallistui neljä naista ja neljä miestä. Yksi heistä oli osa-aikatyössä ja muut olivat työttöminä, kuntoutustuella, sairauspäivärahalla tai sairauslomalla. Haastateltavat olivat eri ikäisiä ja asuivat maaseudulla ja suuremmissa kaupungeissa. Kasvokkaisessa haastattelussa käytiin läpi palveluprosessia ja palvelun koettuja vaikutuksia. Haastateltavilta pyydettiin kirjallinen suostumus haastatteluun ja eri aineistojen yhdistämiseen. Haastattelut kestivät keskimäärin puolitoista tuntia. Lisäksi haastateltiin viittä palveluun osallistuneen omaohjaajaa ja neljää kuntoutusaloitteen tekijää eli henkilöä, joka oli ehdottanut osallistujalle palvelua. Ammatilliseen kuntoutusselvitykseen osallistuville määritellään kuntoutusyksikössä omaohjaaja. Omaohjaaja neuvoo ja ohjaa kuntoutujaa yksilöllisten tavoitteiden laatimisessa ja seuraa niiden toteutumista, tukee kuntoutujan ammatillisten tavoitteiden etenemistä ja on tarvittaessa yhteydessä Kelaan ja muihin tahoihin (Kela 2019, 17). Kuntoutusaloitteen tekijät edustivat joko työvoimahallintoa tai terveydenhuoltoa. Yksi haastatteluista toteutettiin kasvokkain ja loput puhelimitse. Kaikilta omaohjaajilta ja kuntoutusaloitteen tekijöiltä pyydettiin suullinen suostumus haastatteluun, ja suostumus tallennettiin nauhalle. Haastattelut kestivät keskimäärin tunnin. Haastattelussa käsiteltiin palve- luun liittyvää uudistusta sekä prosessin etenemistä tietyn asiakkaan kohdalla. Haastatteluaineisto järjestettiin Muutos-hankkeen osatutkimusta varten palveluprosessin kulkua mukaileviin kategorioihin, ja analyysissa lähdettiin liikkeelle tästä jäsennyksestä. ${ }^{2}$

Palveluun osallistuneille asiakkaille suunnattiin postikysely vuonna 2016. Tässä artikkelissa hyödynnetään vastauksia kahteen avoimeen kysymykseen: "Millaisista asioista on ollut eniten haittaa kuntoutumisen kannalta?” (151 vastausta) sekä "Millaista palautetta haluat antaa ammatillisen kuntoutusselvityksen toteuttamisesta kuntoutusyksikössä?" (149 vastausta). Kysymykset valittiin sillä perusteella, että vastauksissa nostettiin monipuolisesti esiin yhteistoimintaan liittyviä seikkoja. Ulkopuolelle rajattiin analyysin fokukseen liittymättömät vastaukset ja ensimmäisen kysymyksen vastauksista ne, joissa viitattiin ainoastaan työkyvyn haittatekijöihin tai kommentoitiin neutraalisti niiden puuttumista. Analyysiin jäi 57 vastausta. Toisen kysymyksen vastauksista rajattiin analyysin ulkopuolelle lyhyet positiiviset tai negatiiviset arviot sekä "en osaa sanoa" -vastaukset. Tämän kysymyksen osalta vastauksia jäi rajauksen jälkeen analyysiin 97. Aineisto painottuu siis kokonaisuudessaan palveluun osallistuneiden asiakkaiden näkemyksiin ja kokemuksiin. Tämä heijastuu myös aineiston analyysiin. Haastattelujen määrä on myös suhteellisen vähäinen. Kyselyiden avoimet vastaukset täydentävät kuitenkin aineistoa erityisesti asiakkaiden osalta ja mahdollistavat tulkintojen laajemman suhteuttamisen. Vaikka aineisto perustuu ensisijaisesti Kelan ammatilliseen kuntoutusselvitykseen, puhutaan jatkossa 
myös yleisemmin palvelusta tai kuntoutuspalvelusta, koska osa aineistosta laajenee sisällöllisesti tietyn palvelun ulkopuolelle.

Analyysissa hyödynnettiin käsitelähtöistä temaattista analyysia. Huomiota kiinnitettiin kuntoutuksen osapuolten yhteistoimintaan ja siihen kytkeytyviin toiminta- ja ajattelutapoihin, palvelujen ja järjestelmien välisiin rajapintoihin sekä kuntoutuksen osapuolilta odotettaviin asemiin ja kykyihin (vrt. Romakkaniemi ym. 2018). Haastatteluja ja kyselyiden vastauksia käsiteltiin kokonaisuutena. Järjestetty ja rajattu aineisto analysoitiin keskittymällä jaetun toimijuuden kannalta keskeisiin yhteistoiminnan prosesseihin: suunnitteluun ja päätöksentekoon sekä sitoutumiseen, vastuuseen ja tukeen. Tulkitsevassa analyysissa muodostettiin näihin prosesseihin liittyvät pääteemat ja niiden alateemat. Teemojen tunnistamiseen tai muodostamiseen ei ole olemassa tarkkoja sääntöjä, ja teemojen rakentaminen sisältää jo itsessään tulkintaa. Kyse on kaikkiaan aineiston tulkitsemisesta ja ymmärtämisestä, ei ainoastaan sen tiivistämisestä tai kategorisoinnista. (Braun \& Clarke 2006.) Analyysissa pyritään ymmärtämään myös teemojen välisiä suhteita (Castleberry ja Nolen 2018). Artikkelissa seuraavaksi käsitellyt teemat esiintyivät aineistossa toistuvasti muodostaen tietynlaisen kuvion tai kaavan (pattern), joka tuntui tiivistävän jotain olennaista suhteessa tutkimustehtävään (ks. Braun \& Clarke 2006). Suunnittelun ja päätöksenteon prosesseihin liittyvä pääteema koski jaettua toimijuutta haurastuttavia jäykkiä ja jännitteisiä toimintatapoja. Sitoutumisen, vastuun ja tuen prosesseihin liittyvä pääteema koski puolestaan normatiivi- sia ajattelutapoja ja niiden myötä tunnistamatta jääviä tarpeita.

\section{JÄNNITTEISET JA JÄYKÄT TOIMINTATAVAT}

- TURHAUTUMINEN JA VOIMATTOMUUS

\section{Taivuttavat ja ohittavat toimintatavat}

Suunnitteluun ja päätöksentekoon fokusoiminen tarjoaa erään näkökulman jaetun toimijuuden tarkasteluun. Yhteinen suunnittelu korostuu ammatillisessa kuntoutusselvityksessä, jossa ammatillisen kuntoutussuunnitelman laatiminen on keskeisessä roolissa. Suunnitelma laaditaan moniammatillisen työryhmän ja palvelun osallistujan yhteistyönä. Kuntoutussuunnitelma näyttäytyy siis tietyllä tavalla palvelun lopputuloksena. Sen laatimisesta ja toteutumisen seurannasta vastaa palvelua toteuttanut kuntoutusyksikkö, erityisesti osallistujalle määritelty omaohjaaja (ks. Kela 2019). Haastatteluissa kerrotaan, että ammatillisen kuntoutussuunnitelman tulee olla yksilöllisesti räätälöity ja osallistujan omakseen kokema. Samanaikaisesti suunnitelman tulee olla eri osapuolten - myös “yhteiskunnan” kannalta realistinen:
Elikkä tässähän nyt, kun täällä kuitenkin pitää pyrkiä siihen realistiseen ammatilli- seen kuntoutuksen suunnitelmaan, eli se pitää olla nimenomaan realistinen tietysti kuntoutujan itsensä kannalta ja myös sitten tietysti yhteiskunnan kannalta. (Omaoh- jaaja)

Mikä on "realistista” ja "omaksi koettavaa" ja miten näitä kahta painotetaan, on suunnitelman laatimisen prosessissa jatkuvan neuvottelun alla. Neuvottelut saattavat sisältää tietynlaista komp- 
romissityöskentelyä, jossa toimijuus tulee vaihtelevasti jaetuksi. Palvelun osallistuja ja moniammatillinen tiimi tai omaohjaaja eivät aina jaa näkemystä tietyn suunnitelman tai tavoitteen realistisuudesta. Suunnitelmaa laadittaessa ja jatkotoimenpiteitä pohdittaessa neuvotellaan esimerkiksi siitä, missä määrin henkilön on hyödynnettävä aiempaa koulutustaan ja onko mahdollista suunnitella alanvaihtoa. Palvelun tavoitteiden ja toteuttajatahon vastuiden kautta määrittyvä realistisuus ei välttämättä ole linjassa osallistujan alusta aloittamisen kaipuun tai omia rajoitteita koskevien kokemusten kanssa. Tämän kaltaisia kokemuksia ei myöskään ole välttämättä helppo sanoittaa tai jakaa. Näin ollen ne eivät aina välity edes omaohjaajalle. Joskus kompromissityöskentelystä seuraakin suunnitelma, jota osallistujan on vaikea tunnistaa omakseen; se on enemmänkin jonkinlainen taipumisten ja myöntymisten summa, eikä osallistuja koe tulleensa täysin kuulluksi. Osapuolten yhteistoiminta on kuitenkin järjestelmän näkökulmasta toiminut: suunnitelma on laadittu ja tavoitteista on sovittu. Sopimuksellinen kuntoutus ei kuitenkaan aina tarkoita jaettua toimijuutta,jos jaettua toimijuutta lähestytään yhteisten intentioiden näkökulmasta (vrt. Romakkaniemi \& Järvikoski 2012; Roth 2017).

Osapuolten näkemykset osallistujan terveydentilasta, työkyvystä tai työllistymismahdollisuuksista saattavat myös erota toisistaan. Joskus osallistuja kokee psyykkisen tai fyysisen terveydentilansa huonommaksi kuin moniammatillinen tiimi:

Ihminen jolla on kovat kivut ei kykene tekemään enään asioita mitä ennen. Jos ohjaaja ei minun kipuja tunne niin se on masentavaa kun hoetaan kyllä sä pystyt ja senkus nyt menet kokeilemaan. Minä tiedän itse mitä pystyn tekemään ja mitä en. (Osallistuja, kysely)

Vastaavasti moniammatillinen tiimi saattaa nähdä osallistujan työllistymismahdollisuudet ja resurssit positiivisemmassa valossa kuin osallistuja itse, jolloin esimerkiksi uudelleenkouluttautumiselle ei nähdä olevan perusteita. Ymmärryksen puutetta koetaan erityisesti silloin, kun oma sairaus tai muu työkyvyn rajoite on harvinainen, luonteeltaan vaihteleva tai vaikeasti todennettava.

Myös kuntoutusyksikön työntekijöiden näkemykset ja Kelan lopulliset, esimerkiksi osallistujan taloudellista toimeentuloa määrittävät päätökset saattavat olla keskenään ristiriitaisia. Kuntoutusyksikössä esimerkiksi päädytään suosittelemaan - yhteisymmärryksessä osallistujan kanssa - työkyvyttömyyseläkettä, mutta sitä ei kuitenkaan myönnetä. Koska eri toimijoiden väliset valta- ja vastuusuhteet eivät ole yleisesti eikä palveluihin osallistuville näkyviä, saattavat epäjohdonmukaisuudet synnyttää kokemuksen järjestelmän kasvottomuudesta ja epäloogisuudesta. Läpinäkyvyyden puutteen vuoksi voi olla vaikeaa ymmärtää, miksi kuntoutusyksikön suositukset eivät tunnu vaikuttavan niihin päätöksiin, jotka lopulta määrittävät ihmisten reaalisia mahdollisuuksia. Changin (2010) mukaan jaettu toimijuus koostuu muun muassa toisen näkökulman ymmärtämisestä. Kuvatun kaltaisissa tilanteissa henkilö voi kokea, ettei sen enempää hänen kuin kuntoutusyksikön ammattilaisten näkemystä tilanteesta ymmärretä tai huomioida. 
Eräs kielteisen työkyvyttömyyseläkepäätöksen saanut haastateltava kuvaa:

Ja teillä sitten teidän lääkärit mitkä ei ole - - ikinä mua nähnytkään saatikka sitten hoitanut mua, niin ne sanoo että mä olen täysin terve ja työkykyinen. Niin eikö tämä ole pikkasen ristiriidassa tämä homma. Mä ajattelin että ei jumalautsi, että kyllä se söi miestä rotan lailla. (Osallistuja, haastattelu)

Ammatillisen kuntoutussuunnitelman laatiminen tapahtuu aina tietyssä institutionaalisessa ja organisatorisessa kehyksessä ja tietyillä reunaehdoilla. Palvelun toteutusta ohjaava palvelukuvaus määrittää, ketkä suunnitelman laatimiseen osallistuvat ja millaisista positioista ja vastuista käsin, mitä suunnitelma sisältää ja mikä rooli suunnitelmalla on sekä kyseisessä palvelussa että kuntoutusjärjestelmässä laajemmin. Jännitteet palvelukuvauksen ja kuntoutustyön arjen sekä objektiivisen ja subjektiivisen työkyvyn välillä voivat kääntyä joissain olosuhteissa ohitetuksi tulemisen tunteiksi.

Suunnitelman laatimisen prosessiin liittyvien kokemusten lisäksi aineistossa kerrotaan palvelun toteutukseen liittyvistä toimintatavoista, jotka on koettu jollain tavoin pakottaviksi tai syrjiviksi. Osallistuja on voinut kokea esimerkiksi ryhmätilanteisiin liittyvää pakkoa:

Älkää laittako ihmisiä kertomaan omasta tilanteestaan ryhmässä. Se ei kuulu muille osallistujille! Se on nöyryyttävää. (Osallistuja, kysely).

Myös muuhun kuin terveydentilaan liittyvien, yksilöllisten ominaisuuksien ja tarpeiden huomiointi koettiin joskus puutteelliseksi. Syrjinnän kokemusten yhteydessä viitattiin esimerkiksi kieliongelmiin ja tulkin puutteeseen tai sukupuoli-identiteetin moninaisuuden ohittamiseen. Tämänkaltaiset kokemukset eivät olleet aineistossa yleisiä, mutta osoittavat sen, että kuntoutuspalvelu ei ole irrallinen yhteiskunnan syrjivistä rakenteista.

\section{Rytmihäiriöt}

Jaetun toimijuuden mahdollisuuksiin liittyy aineistossa ajallinen ulottuvuus eli se, millainen tasapaino kuntoutuspalvelun rytmien ja osallistujien subjektiivisten rytmien välillä vallitsee. Palvelun rytmit sisältävät lainsäädännöllisiä, institutionaalisia ja organisatorisia rytmejä. Osallistujien subjektiiviset rytmit sisältävät puolestaan sekä yleiseen elämäntilanteeseen ja terveydentilaan liittyviä rytmejä että arjen mikrorytmejä. Palvelun rytmien ja osallistujien rytmien välisellä tasapainolla näyttää olevan merkitystä jaetun toimijuuden rakentumisen kannalta. Ammatillisen kuntoutuksen yhteydessä puhutaan paljon toimenpiteiden oikea-aikaisuudesta. Aineiston perusteella oikea-aikaisuus kytkeytyy tiiviisti kysymyksiin toimenpiteiden tarkoituksenmukaisuudesta sekä osallistujan vaikutusmahdollisuuksista.

Rytmien välisessä tasatahtisuudessa näyttää olevan ensinnäkin kyse siitä, että osallistujalla on tarvittavat resurssit palvelun läpikäymiselle ja sen potentiaalisen hyödyn realisoitumiselle. Ihmisten subjektiiviset rytmit ovat kuitenkin alati vaihtelevia. Niitä saattaa olla haasteellista sovittaa pysyväisluontoisempiin institutionaalisiin rytmeihin siten, että palvelu toteutuisi osallistujan kannalta parhaalla mahdollisella hetkellä. Pal- 
veluun epäsuotuisaan aikaan osallistuminen saattaa kuluttaa entisestäänkin vähäisiä voimavaroja. Osallistujan terveydentila saattaa olla hetkellisesti erityisen huono tai kyky omaksua uutta ja suunnitella tulevaa heikentynyt esimerkiksi monimutkaisten perhetilanteiden ja hoivavastuiden vuoksi. Tämänkaltaiset dynaamiset tilanteet eivät kuitenkaan aina kirjaudu dokumentteihin, joiden perusteella palveluita myönnetään ja ajoitetaan. Mikäli palvelun ajankohdasta ei tällöin ole mahdollista neuvotella, ei ihminen koe tulleensa kuulluksi. Näin saattaa käydä erityisesti tilanteissa, joissa palvelun ajoitusta sanelevat erilaiset lainsäädännölliset ehdot:

Haastattelija: No sä jaksoit kuitenkin sen kolme päivää siellä olla. Osallistuja: No pakko, no pakkohan se oli [naurahtaa]. Jos minä olisin lähtenyt kesken sieltä niin ei minun kuntoutushakemusta oltaisi käsitelty enää. Että tällä lailla yhteiskunta pystyy sinut laittamaan selkä seinää vasten, sulla ei ole vaihtoehtoa. Jos minä vastaisinkin itse omasta elämästä mutta kun minä vastaan neljän muun. Niin se on, sehän on pakko olla se säännöllinen tulo, että pystyy hoitamaan sitten kaikki muut. (Osallistuja, haastattelu)

Siteerattu haastateltava painottaa, että kyse on nimenomaan palvelun väärästä ajoituksesta - hän ei ole sanojensa mukaan "työtä vieroksuva", hänen voimavaransa eivät vain juuri kyseisessä hetkessä riitä tulevaisuuden pohtimiseen palvelun edellyttämällä tavalla. Jatkossa tilanne voi olla eri ja sitä myös haastateltava toivoo. Vaikka palvelun ajoitukseen liittyy epätahtisuutta, syntyy palvelussa myös kuulluksi tulemisen kokemuksia. Haastateltava jatkaa:
Kyllä se lääkri sanoi heti että ei sekään oikein ymmärtänyt miksi minä olen siellä [naurahtaa].

Osallistujan resurssipula tulee kuulluksi ja ymmärretyksi; hän toteaa yhteisymmärryksessä työntekijöiden kanssa, ettei palvelun jatkamiselle ole edellytyksiä. Ymmärtämättömyyden kokemus kohdistuukin kuntoutustyöntekijöiden sijaan kasvottomaan "yhteiskuntaan”.

Palvelun ajalliseen ulottuvuuteen kytkeytyvät aineistossa myös tietynlaiset mikrorytmit. Jaetun toimijuuden rakentumiseen vaikuttaa se, miten samaa tai eri tahtia standardoidun palvelun mikrorytmit ja osallistujan subjektiiviset mikrorytmit kulkevat. Osallistujissa herää turhautumisen ja ohitetuksi tulemisen tunteita, mikäli rytmien tasatahtisuus eri syistä horjuu. Aineistossa kerrotaan palvelun toteutukseen liittyvästä kiirehtimisen tunteesta; asioita tulee eteen runsaasti ja nopealla tahdilla, eikä ratkaisuja ole aina mahdollista pohtia tarpeeksi omatahtisesti. Toisaalta toteutukseen voi liittyä myös negatiiviseksi koettua toistoa ja odottelua. Vaikka asioiden jakaminen työntekijöiden kanssa on usein myönteinen kokemus, toistuessaan se alkaa turhauttaa:

Jatkuva samojen asioiden vatvominen, ikävien asioiden kertaaminen ja uudelleen eri ihmisille kertominen. (Osallistuja, kysely)

Myös tarpeeton odottelu tai "täyteohjelmaksi" koettu toiminta kuntoutuspäivien aikana voivat herättää tunteen epäkunnioittavasta kohtelusta. "Tyhjän panttina istuttaminen" voidaan kokea osoitukseksi siitä, että osallistujien aikaa ei kunnioiteta. Tilanteissa on osaltaan kyse palvelukuvauksen ja kuntoutusyk- 
sikön arkitodellisuuden välisistä jännitteistä. Nämä jännitteet saattavat ilmetä osallistujien kokemuksina epätarkoituksenmukaisesta toiminnasta ja omien vaikutusmahdollisuuksien vähäisyydestä. Jännitteet saattavat herättää myös kuntoutustyöntekijöissä turhautumista.

Kiirehtimisen ja toiston lisäksi saattaa jossain palvelun vaiheessa herätä tunne siitä, että mitään ei oikeastaan tapahdu; aika ikään kuin pysähtyy. Palvelun vaiheiden välillä saattaa olla taukoja:

Kaikkien vaiheitten välillä oli odottamista. Milloin jonkun päätöksen, milloin aloitusajan. Vähän ärsytti välillä kun tuntui, ettei mitään tapahdu. (Osallistuja, kysely)

Asioiden koetaan etenevän hitaasti ja kankeasti, ja byrokratiaan liittyvä "veivaaminen" kuluttaa voimavaroja. Toisaalta ajan pysähtymisen kokemus saattaa herätä vasta kun palvelu on jo ohi. Palvelu on voitu kokea toteutukseltaan onnistuneeksi, henkilökohtaisesti antoisaksi ja tulevaisuutta koskevia suunnitelmia on tehty hyvässä yhteisymmärryksessä. Palvelun jälkeen osallistuja saattaa kuitenkin hämmentyneenä pohtia, oliko tämä tässä. Palvelussa rakennettu jaettu toimijuus haurastuu, ja osallistuja kokee jäävänsä yksin. Aineiston perusteella näyttää siltä, että kuntoutusjärjestelmä sisältää samaan aikaan sekä jyrkästi rajattuja että toistavia ajallisia elementtejä. Lyhytkestoiset toimenpiteet seuraavat usein toisiaan. $\mathrm{Ne}$ saattavat päättyä joko jyrkästi ei-mihinkään tai vastaavasti synnyttää tunteen loputtomasta toistosta:

- - ei tavallaan sitten tule sitäkään ratkaisua että riittäisi että nyt pistetään vaikka eläkkeelle - - Mutta sitten kun sitä vaan pitää pyöriä ja pyöriä ja tavallaan siinä, semmoisia vähän, se ärsyttää sitten kun ei tiedä että miten pitkään tässä taas ja mitä kaikkea semmoista tulee. Se siinä taustalla on että mitenkä monta paikkaa pitää nyt työkokeilla. (Osallistuja, haastattelu)

\section{NORMitTAVAT AJATtelutavat JA NÄKYMÄTTÖMIIN JÄÄVÄT TARPEET - HÄMMENNYS JA NÄKÖALATTOMUUS}

Motivoituneisuuden ideaali ja sivuun jäämisen riski

Jaetussa toimijuudessa keskeistä on myös sitoutuminen yhdessä laadittuihin suunnitelmiin sekä yhteinen vastuu ja tuki (ks. Chang 2010). Aineisto sisältää viitteitä siitä, että erityisesti pitkäjänteiseen, molemminpuoliseen sitoutumiseen ja vastuuseen liittyvät epäselvyydet ja puutteet saattavat herättää palvelun osallistujissa hämmennystä ja näköalattomuutta. Nämä tuntemukset osoittavat sekä palvelun häiriöille alttiita kohtia että sen, miten yksittäinen palvelu laajenee väistämättä yli organisatoristen ja ajallisten rajojensa. Näin ollen jaetun toimijuuden rakentumisen kannalta olennaisina näyttäytyvät myös kuntoutuksen rajapinnat muihin järjestelmiin.

Jaetun toimijuuden rakentumiselle tai haurastumiselle tarjoutuu paikkoja jo ennen kuntoutuspalvelun aloittamista; potentiaalisen osallistujan on ensinnäkin saatava tietoa palvelun olemassaolosta ja siihen hakemisesta. Ammatilliseen kuntoutusselvitykseen osallistuvien kohdalla hakemista koskevan aloitteen tekee usein Kela, TEtoimisto tai työllistymistä edistävä monialainen yhteispalvelu (Åkerblad ym. 2018). Aineistossa kerrotaan tilanteista, 
joissa palveluun hakeutuminen on eri syistä viivästynyt tai jäänyt kokonaan toteutumatta. Kyse saattaa olla siitä, että mikään taho ei ota ensisijaista vastuuta henkilön ohjaamisesta palveluun. Vastuullista tahoa koskevan epäselvyyden lisäksi haastatellut omaohjaajat ja kuntoutusaloitteen tekijät viittaavat resurssipulaan, virkailijavaihdoksiin sekä ammatillisia kuntoutuspalveluja koskevan tiedon puutteeseen. Nämä vaikuttavat osaltaan siihen, että palvelua ei löydetä tai siihen ohjaudutaan tarpeettoman myöhään, kun ongelmat ovat ehtineet kasautua ja osallistumisen kynnys noussut.

Toisaalta palvelun ulkopuolelle saattaa rajautua potentiaalisia osallistujia siksi, etteivät he vaikuta hakuvaiheessa tarpeeksi "motivoituneilta". Aineistossa on viitteitä siitä, että osallistujan motivaatio ja sitoutuminen nähdään palveluun osallistumisen keskeisinä edellytyksinä. Jotkut haastatellut palvelun osallistujat olivat suhtautuneet palveluun lähtökohtaisen epäilevästi. Eräs - ammatillisen kuntoutusselvityksen lopulta hyvin antoisaksi kokenut - haastateltava kertoo, että hän ei ollut aluksi erityisen halukas osallistumaan palveluun. Läheisen myötävaikutuksella hän kuitenkin suostui. Keskustelu jatkuu seuraavasti:

Haastattelija: No osaatko sä sanoa minkä takia oli semmoinen olo että en mä nyt tiedä haluanko mä lähteä? Haastateltava: - - kun ei ollut käynyt niin se tuntui sillä tavalla että saanko mä siitä hyötyä. Ehkä siitä tuli sellainen olo että onko se mulle, tuottaako se mulle mitään [naurahtaa]. Että sellainen siinä varmaan oli se... että onko siitä sellaista apua [naurahtaa]. (Osallistuja, haastattelu)
Jotkut haastatellut osallistujat olivat puolestaan pohtineet etukäteen, sopivatko he palveluun vai ovatko he esimerkiksi liian terveitä osallistuakseen "kuntoutukseen". Joidenkin kohdalla osallistuminen herätti epäilyä siksi, että muutosta ei syystä tai toisesta koettu enää omalla kohdalla mahdolliseksi. Aineiston perusteella näyttää siltä, että "motivaation" ja "palvelun tavoitteisiin sitoutumisen" puutteen sijaan kyse saattaa joissain tilanteissa olla häiriöistä tiedon ymmärrettävässä välittämisessä ja yhteisessä käsittelyssä. Edellä mainitut epäilyt saattavat jäädä kokonaan käsittelemättä, jolloin ihminen on vaarassa jäädä palveluiden ulkopuolelle. Jos jaettua toimijuutta olisi rakennettu jo ennen palvelua, olisi "motivaatiota" voitu yhdessä herätellä.

Aktiivisuuden ideaali ja ongelmat prosessihäiriöiden käsittelyssä

Aineistossa kerrotaan myös palvelun muodolliset rajat ylittävän tuen tarpeesta. Ammatillisen suunnitelman toteutumisen kuvataan olevan usein kiinni osallistujan omasta toimeliaisuudesta:

No se [kuntoutussuunnitelman toteutuminen] varmaan riippuu myöskin siitä asiakkaan omasta aktiivisuudesta, että mä luulen että sen kuntoutusjakson jälkeen aika paljon jää sen asiakkaan itsensä hoidettavaksi. (Kuntoutusaloitteen tekijä).

Eräs kyselyyn vastannut osallistuja kuvaa, että jääminen yksin oman aktiivisuuden varaan on haitannut kuntoutusta. Aktiivisuuden ja itsenäisyyden vaade sekä pitkäjänteisen, organisaatioiden ja järjestelmien rajat ylittävän tuen puute kolahtaa erityisesti niihin, joilla ei ole juuri kyseisellä hetkellä tä- 
mänkaltaiseen toimintatapaan tarvittavia resursseja. Eräs kuntoutusaloitteen tekijä kertoo:

No tämän kohdalla tietysti tämä oli, kun on tämmöisestä aktiivisesta ihmisestä kysymys ja munta niin tämä on mennyt mun mielestä tosi hienosti. Mutta sitten on tietysti niitä ihmisiä jotka sitten ei otakaan [kuntoutusaloitteen tekijään] enää yhteyttä ja mä en tiedä että onko hän ollut kurssilla vai eikö hän ole ollut ja meillä ei mitään palautetta tule tänne. - - Joidenkin asiat voi olla että jää kyllä rempalleen sitten että jos ei ole semmoisia, itse aktiivisesti asioita hoitavia. Niin että voi jäädä sinne jonnekin kotiin odottelemaan ja ihmettelemään ja, tai muuta. (Kuntoutusaloitteen tekijä)

Eräässä kyselyvastauksessa kuvaillaan palvelun jälkeisen tuen puutetta:

Kuntoutus sinällään ei antanut eväitä elämään. Jäin kaipaamaan käytännön neuvoja kuinka jatkan elämässä eteenpäin. (Osallistuja, kysely)

Monet kaipaavat yksittäisten toimenpidesuositusten sijaan tai lisäksi jonkinlaista laajempaa elämänsuunnitelmaa. Tuen tarve jatkuu myös ajallisesti rajatun palvelun ja siihen liittyvien seurantakertojen jälkeen. Kyse on osaltaan toimijuuteen kiinteästi kytkeytyvästä tulevaisuusorientaatiosta (esim. Bandura 2001). Sitoutumisen ja vastuun yksipuolisuus näyttää osaltaan vaikeuttavan jaetun toimijuuden rakentumista. Palveluun osallistuvalta edellytetään motivaatiota ja sitoutumista palvelun tavoitteisiin, mutta vastaavaa sitoutumista ja kokonaisvaltaista vastuunottoa ei välttämättä havaita järjestelmän puolelta:
Opiskelupaikkojen tarjontaa parannetta$v a$, itse koin sen tunteen, että jäin tyhjän päälle killumaan. - - Siihen panostusta paremmin, minullekin luvattiin että tullaan seuraamaan kuinka pärjään opiskelupaikan saannin kanssa, toisin kävi. (Osallistuja, kysely)

- - mä sillä tavalla näen tavallaan vähän, tai näenkin näköalattomana sen. Että kun sieltä ei ole löytynyt sitä, mikä se olisi semmoinen mistä saisi, mihinkä pystyy ja tämä olisi semmoinen juttu mihinkä voisi ajatella tekevänsä työkseen sitten. (Osallistuja, haastattelu)

Edelliset lainaukset tuovat esiin tietynlaisia häiriöitä kuntoutuspalvelun prosessissa, kun prosessia tarkastellaan nimenomaan osallistujien kokemusten kautta.Vaikka ammatillinen kuntoutussuunnitelma olisi laadittu, on monen osallistujan tilanne palvelun jälkeen epävarma. Suunnitelmat eivät aina syystä tai toisesta toteudu, ne osoittautuvat epärealistisiksi tai itselle sopimattomiksi. Joskus kaikkia osapuolia tyydyttäviä vaihtoehtoja ei ole pyrkimyksistä huolimatta löydetty tai suunnitelma on jäänyt osallistujalle epäselväksi. Erityisesti näissä tilanteissa osallistuja voi kokea jääneensä palvelun jälkeen tyhjän päälle. Palvelu voidaan kokea turhaksi: mikään ei sen myötä oikeastaan muuttunut tai ratkennut, ja järjestelmä vetäytyy yhteiseksi mielletystä vastuusta.

Näin näyttää tapahtuvan erityisesti, jos palvelu ei ole edennyt formaalin kaavan mukaan tai osallistuja ei ole toiminut aktiivisen ja itsenäisen kuntoutujan ideaalin mukaisesti. Järjestelmä ei välttämättä tunnista ja näin ollen myöskään pysty käsittelemään tämän kaltaisia normittaviin ajattelutapoihin kytkeyty- 
viä prosessihäiriöitä. Tilanteet saattavat herättää myös kuntoutustyöntekijöissä riittämättömyyttä. Joskus prosessihäiriöt jäävät kaikilta osapuolilta näkymättömiin: osallistujat voivat palvelun jälkeen pudota järjestelmien väliseen kuiluun eikä kukaan tiedä, mitä heille ja heidän suunnitelmilleen kuuluu. Tähän näyttää liittyvän järjestelmien välisen tiedonkulun ongelmia ja vastuunjaon epäselvyyksiä:

Että esimerkiksi mä en tiedä tämän [palveluun osallistuneen] kohdalta, että kun täallä on näitä suunnitelmia että miten niin näistä silloin tehdyistä suunnitelmista on päädytty siihen tilanteeseen missä nyt ollaan, kun mä täältä nyt näitä [tietoja] katson ja katson sitä, että mitä tässä on sitten tapahtunut sen jälkeen. Niin mietin että siinä on kuitenkin aikamoinen, niin sanottu musta aukko. (Kuntoutusaloitteen tekijä)

\section{Pohdinta}

Tässä tutkimuksessa tarkastelimme jaettua toimijuutta haurastuttavia toimintaja puhetapoja ammatillisen kuntoutuksen yhteistoiminnassa. Analyysin perusteella yhteiseen suunnitteluun ja päätöksentekoon liittyvien toimintatapojen jäykkyys ja jännitteisyys haurastuttivat jaettua toimijuutta. Kuntoutuspalvelu toteutettiin tietyssä lainsäädännöllisessä, institutionaalisessa ja organisatorisessa kehyksessä, johon palveluihin osallistuvien subjektiiviset rytmit ja tarpeet eivät aina saumattomasti istuneet. Jännitteet palvelun rakenteellisen kehyksen ja kuntoutustyön arkitodellisuuden välillä turhauttivat myös ammattilaisia. Kokemusten voidaan tulkita heijastavan sitä, että ammatillisen kuntoutuksen siirtymä järjestelmälähtöisyydestä kohti asiakaskeskeisyyttä on vielä kesken. Sitoutumisen, vastuun ja tuen prosesseissa motivoituneisuuteen ja aktiiviseen toimijuuteen liittyvät kuntoutuksen ajattelutavat saattoivat vaikeuttaa jaetun toimijuuden rakentumista. Tämänkaltaisia haasteita ei ole helppo tunnistaa, koska ne eivät liity ainoastaan palveluiden toteuttamiseen tai kuntoutuksen konkreettiseen yhteistoimintaan, vaan kuntoutuksen laajempiin rationaliteetteihin (vrt. Lappi \& Lindh 2018).

Palveluiden rajapinnat näyttävät tämän tutkimuksen perusteella olevan jaetun toimijuuden näkökulmasta erityisen tärkeitä. Romakkaniemi, Lindh ja Laitinen $(2018,104)$ toteavat, että palveluiden rajoilla käydään neuvotteluja kuulumisesta ja poissulkemisesta, oikeuksista ja velvollisuuksista. Jaetussa toimijuudessa on kyse vastavuoroisuudesta. Mikäli henkilö jää esimerkiksi palvelun jälkeen vaille tarvitsemaansa tukea, on kyseessä järjestelmän sitoutumiseen ja vastuunottoon liittyvä ongelma, jota ei voi redusoida koskemaan ammattilaisen ja palvelun osallistujan välistä vuorovaikutusta tai yksittäistä palvelua. Palveluiden käyttäjän ja ammattilaisen välisessä suhteessa jaettua toimijuutta murentavat hylkäämisen kokemukset (Romakkaniemi \& Järvikoski 2012). Tämän artikkelin aineisto osoittaa, että hylkäämisen kokemuksia voi syntyä myös instituutioiden ja järjestelmien tasolla ja ehkä ennen kaikkea niiden väleissä, jos tuen ja rohkaisun tarve jää näkymättömiin.

Kuulluksi tulemisen kokemus voidaan nähdä jaetun toimijuuden edellytyksenä, mutta se voi tarkoittaa eri ihmisille eri asioita (Hokkanen 2012, 125). Tä- 
män artikkelin aineiston pohjalta voidaan käänteisesti tulkita, että kuulluksi tuleminen tarkoitti ensinnäkin kuntoutuspalvelun joustavuutta ja koettua tarkoituksenmukaisuutta. Tähän liittyi palvelun sopiva ajoitus sekä palvelun toteuttaminen kaikille osapuolille mielekkäällä tavalla. Tarkoituksenmukaisuuden kokemusta vahvistivat tiedon ymmärrettävä välittäminen ja yhteinen käsittely (vrt. Romakkaniemi \& Järvikoski 2012). Kuulluksi tulemiseen liittyi myös tasaarvoinen neuvotteluasema ja kokemus jaetusta ymmärryksestä; osallistujan tunne siitä, että hänen omia toiveitaan ja tavoitteitaan ei ainoastaan huomioida, vaan niistä syntyy myös yhteinen ymmärrys. Jaetun toimijuuden voidaan nähdä edellyttävän, että kuntoutuksen vuorovaikutukselliset rakenteet mahdollistavat nimenomaan yhteiset intentiot (vrt. Roth 2017). Lisäksi kuulluksi tulemiseen liittyi palvelun rajat ylittävän tuen tarpeen tunnistaminen ja käsittely. Kaikkiaan kuulluksi tulemisessa näytti olevan kyse mahdollisuudesta osallistua palvelun käytäntöjä ja suunnitelmia koskeviin neuvotteluihin täysivaltaisena jäsenenä - mutta myös tulla aidosti ymmärretyksi ja saada tarvittaessa kannattelua.Tämä tarve saattaa olla läsnä juuri erityistä epävakautta sisältävissä elämän muutostilanteissa.

Kuulluksi tulemisella tai kuulematta jäämisellä on myös konkreettisia seurauksia. Kyse ei ole "ainoastaan" palveluihin osallistuvien kokemuksista vaan heidän taloudellisista, ammatillisista ja sosiaalisista resursseistaan. Jaetun toimijuuden haurastuminen saattaa näyttäytyä passiivisena ei-tapahtumisena, mutta toisesta kulmasta katsottuna se voidaan nähdä aktiivisena institutionaalisena ja yhteiskunnallisena sivuun jättämisenä. Bratmanin (1992) mukaan molemminpuolinen responsiivisuus on jaetun toimijuuden ehto. Tämä tarkoittaa sitä, että toimijat ovat responsiivisia toisen intentioille ja toiminnoille, tietäen että toinen yrittää tehdä samoin.Vaikuttaakin siltä, että erityisen hämmentäviksi koetaan epäjohdonmukaisuudet kuulluksi tulemisen kokemuksen ja sen seurausten välillä. Nämä epäjohdonmukaisuudet näyttävät liittyvän erityisesti järjestelmien sisäisiin ja välisiin, palveluihin osallistuville läpinäkymättömiin valta-vastuu-suhteisiin sekä kuntoutusjärjestelmän julkilausumattomiin normatiivisiin odotuksiin.

Tässä artikkelissa on tietoisesti viitattu hauraaseen jaettuun toimijuuteen esimerkiksi jakamattoman toimijuuden sijaan. Tämä liittyy ajatukseen siitä, että myös yksilöllinen toimijuus rakentuu aina suhteiden verkostoissa (esim. Burkitt 2016) ja toiminta on aina eri tavoin sidoksista (ks. Honkasalo 2014). Tästä näkökulmasta toimijuus ei ole koskaan täysin yksilöllistä tai yhteistä, jaettua tai jakamatonta. Hauraan jaetun toimijuuden käsite voi auttaa haastamaan kuntoutuksen ajattelutavat, joissa kuntoutus nähdään lineaarisena prosessina väliaikaisesti jaetusta tai tuetusta toimijuudesta yksilölliseen toimijuuteen. Aineiston analyysi tukee näkemystä siitä, että jaettu toimijuus ei ole jonkinlainen on-off-tila sen enempää kuin toimijuus ylipäätään (ks. Jyrkämä 2008). Ammatillisessa kuntoutuksessa tuki ja yhteistoiminta ovat keskeisiä elementtejä. Voidaan siis ajatella, että kuntoutukseen liittyy jonkinlainen lähtökohtainen oletus jaetusta toimijuudesta. Jaettu toimijuus voi kuitenkin olla odotettua hauraampaa ja tilannesidonnaisempaa. Sen rakentumisen kontekstuaalisiin eh- 
toihin kannattaa sekä kuntoutuksessa että muissa tukeen perustuvissa interventiossa kiinnittää analyyttista huomiota.

\section{ViITTEET}

1 Kela kilpailuttaa kuntoutusselvityksen palveluntuottajat ja ohjaa palveluiden toteutusta palvelukuvauksilla. Palvelukuvauksen mukaan kuntoutusselvityksen päämääränä on edistää kuntoutujan valmiuksia vastata työmarkkinoiden haasteisiin, tunnistaa ja arvioida hänen työ- ja toimintatai opiskelukykyynsä vaikuttavia tekijöitä, selvittää ammatillisen ja lääkinnällisen kuntoutuksen tarpeet ja mahdollisuudet, ohjata kuntoutujaa tunnistamaan omat mahdollisuutensa ja voimavaransa sekä tukea kuntoutujan työelämässä jatkamista, sinne palaamista tai sinne siirtymistä (Kela 2019, 2). Palveluun sisältyy alkuvaihe (2 - 4 päivää), mahdollinen ammatillisen kuntoutussuunnitelman laatimisen sisältävä jatkovaihe (enintään 9 päivää) sekä seurantavaihe (1 - 3 päivää) (Kela 2019). Kuntoutusselvityksen palvelukuvaus on joiltain kohdin muuttunut tämän artikkelin aineiston keräämisen jälkeen. Aineiston keräämisen aikaan oli voimassa vuoden 2015 palvelukuvaus (ks. Kela 2015c), ja uusi on tullut voimaan vuoden 2019 alusta (ks. Kela 2019).

2 Aineistolainausten yhteydessä mainitaan kuitenkin puhujan positio sekä palvelun osallistujien kohdalla aineistokokonaisuus, johon lainaus sisältyy (haastattelu tai kysely). Tekstissä viitataan systemaattisesti palvelun osallistujiin tai palvelun käyttäjiin, ei esimerkiksi kuntoutujiin. Neutraalilla ilmaisulla pyritään välttämään erilaisia institutionaalisia konnotaatioita.

\section{KirJallisuUs}

Andersson, Johanna \& Ahgren, Bengt \& Bihari Axelsson, Susanna \& Eriksson, Andrea \& Axelsson, Runo (2011) Organizational approaches to collaboration in vocational rehabilitation - an internatio- nal literature review. International Journal of Integrated Care 11, e137. https:// doi.org/10.5334/ijic.670

Bandura, Albert (2001) Social cognitive theory: an agentic perspective. Annual Review of Psychology 52,1-26. https:// doi.org/10.1146/annurev.psych.52.1.1

Bandura, Albert (2000) Exercise of human agency through collective efficacy. Current Directions in Psychological Science 9 (3), 75-78. https://doi. org/10.1111/1467-8721.00064

Burkitt, Ian (2016) Relational agency: Relational sociology, agency and interaction. European Journal of Social Theory 19 (3), 322-339. https://doi. org/10.1177/1368431015591426

Bratman, Michael (2009) Shared agency: A planning theory of acting together. Oxford: Oxford University Press.

Bratman, Michael (1992) Shared cooperative activity. Philosophical Review 101 (2), 327-341. https://doi. org/10.2307/2185537

Braun, Virginia \& Clarke, Victoria (2006) Using thematic analysis in psychology. Qualitative Research in Psychology 3 (2), 77-101. https://doi. org/10.1191/1478088706qp063oa

Castleberry, Ashley \& Nolen, Amanda (2018) Thematic analysis of qualitative research data. Is it as easy as it sounds? Currents in Pharmacy Teaching and Learning 10 (6), 807-815. https://doi. org/10.1016/j.cptl.2018.03.019

Chang, Esther S. \& Heckhausen, Jutta \& Greenberger, Ellen \& Chuansheng, Chen (2010) Shared agency with parents for educational goals: ethnic differences and implications for college adjustment. Journal of Youth and Adolescence 39 (11), 1293-1304. https://doi. org/10.1007/s10964-009-9488-7

Haapakoski, Kaisa \& Åkerblad, Leena \& Tolvanen, Asko \& Mäntysaari, Mikko \& Ylistö, Sami \& Kannasoja, Sirpa (2018) Kelan ammatillisen kuntoutuksen lakiuudistus. Ihanteet, toimeenpano ja harkintavalta. Sosiaali- ja terveysturvan raportteja. Helsinki: Kela. http://urn.fi/ URN:NBN:fi-fe2018112749301 Luettu 6.8.2020.

Harra, Toini (2014) Terapeutttinen yhteistoiminta. Asiakkaan osallistumisen mah- 
dollistaminen toimintaterapiassa. Rovaniemi: Lapin yliopisto,

Hokkanen, Liisa (2012) Interpreting a client satisfaction survey on shared agency in plan-based practice at the welfare office. Nordic Social Work Research 2 (2), 119-135. https://doi.org/10.1080/2156 857X.2012.710177

Honkasalo, Marja-Liisa \& Ketokivi, Kaisa \& Leppo, Anna (2014) Moniselitteinen ja hämärä toimijuus. Sosiologia 51 (4), 365-372.

Honkasalo, Marja-Liisa (2013) Katveessa. Pieni toimijuus kriittisenä avauksena toiminnan teoriaan. Tiede \& Edistys 22 (1), 42-61.

Honkasalo, Marja-Liisa (2008) Reikä sydämessä. Tampere:Vastapaino.

Honkasalo, Marja-Liisa (2009) Grips and ties. Agency, uncertainty, and the problem of suffering in North Karelia. Medical Anthropology Quarterly 223 (1), 51-69. https://doi.org/10.1111/j.15481387.2009.01037.x

Jeglinsky, Ira \& Karhula, Maarit \& AuttiRämö, Ilona (2013) Kuntoutusprosessi kuntoutujan arvioimana. Kuntoutus 36 (4), 37-42. https://doi.org/10.3109/096 38288.2013.797511

Jyrkämä, Jyrki (2008) Toimijuus, ikääntyminen ja arkielämä - hahmottelua teoreettis-metodologiseksi viitekehykseksi. Gerontologia 22 (4), 190-203.

Järvikoski, Aila \& Martin, Marjatta \& Autti-Rämö, Ilona \& Härkäpää, Kristiina (2013) Shared agency and collaboration between the family and professionals in medical rehabilitation of children with severe disabilities. International Journal of Rehabilitation Research 36 (1), 30-37. https://doi.org/10.1097/ MRR.0b013e32835692d3

Kela (2015a) Ammatillisen kuntoutuksen lain ja kuntoutusselvityksen uudistus- ja toimeenpanotutkimus (AMKU). https://www.kela.fi/amku-tutkimus Luettu 20.6.2019.

Kela (2015b) Muutos-hanke. https://www. kela.fi/muutos-hanke Luettu 20.6.2019.

Kela (2015c) Kelan avo- ja laitosmuotoisen kuntoutuksen standardi. Ammatillinen kuntoutusselvitys. Voimassa 1.1.2015 alkaen. http://www.kela.fi/documents/10180/
1887882/150316+Ammatillinen+kunt outuselvitys + .pdf/4718a381-3b6d-4fefaf1d-6adb86904f4c Luettu 17.6.2019

Kela (2019) Kelan kuntoutuksen palvelukuvaus. Ammatillinen kuntoutusselvitys, suomenkielinen palvelu. Voimassa 1.1.2019 alkaen. https://www.kela.fi/ documents/10180/9184001/180226+ uusi+LPE+Ammatillinen+kuntoutuss elvitys.pdf/d30c43ff-1cc6-44d3-99dc211833dd74db Luettu 17.6.2019.

Ketokivi, Kaisa \& Meskus, Mianna (2015) The dilemma of 'the capable actor' and the case of disrupted lives. Contemporary Social Science: Journal of the Academy of Social Sciences 10 (1), 39-51. https://doi.org/10.1080/21582041.201 4.988289

Ketokivi, Kaisa (2009) Sharing the same fate. The social bond between the self and fellow sufferers in the context of peer support. European Societies 11 (3), 391-410. https://doi. org/10.1080/14616690902764815

Leplege, Alain \& Gzil, Fabrice \& Cammelli, Michele \& Lefece, Celine \& Pachoud, Bernard \& Ville, Isabelle (2007) Personcentredness. Conceptual and historical perspectives. Disability and Rehabilitation 29 (20-21), 1555-1565. https://doi. org/10.1080/09638280701618661

Lindh, Jari (2013) Kuntoutus tuotetaan toimintaverkostoissa. Kuntoutus 36 (3), 50-61.

Lindh, Jari \& Lappi, Carita (2018) Hallinnan rationaliteetit sosiaalisessa kuntoutuksessa. Kuntoutus 41 (4), 20-33.

Romakkaniemi, Marjo \& Lindh, Jari \& Laitinen, Merja (2018) Nuorten aikuisten osallisuus ja sosiaalinen kuntoutus Lapissa. Sosiaali- ja terveysturvan tutkimuksia 147. Helsinki: Kela. http://urn. fi/URN:NBN:fi-fe201802063157 Luettu 17.6.2019.

Romakkaniemi, Marjo \& Järvikoski, Aila (2013) Jaetun toimijuuden rakentuminen mielenterveyspalveluissa. Kuntoutus 36 (1), 39-44.

Romakkaniemi, Marjo \& Järvikoski, Aila (2012) Service users' perceptions of shared agency in mental health services. European Journal of Psychotherapy \& Counselling 14 (4), 381-394. https:// doi.org/10.1080/13642537.2012.7335 
56

Roth, Abraham (2017) Shared agency.

Teoksessa Edward N. Zalta (toim.) The

Stanford Encyclopedia of Philosophy

(Summer 2017 Edition). Stanford: Stan-

ford University. https://plato.stanford. edu/archives/sum2017/entries/sharedagency Luettu 17.6.2019.

Roth, Abraham (2004) Shared agency and contralateral commitments. Philosophical Review 113 (3), 359-410. https:// doi.org/10.1215/00318108-113-3-359

Ruuskanen-Parrukoski， Pirkko (2017) Palveluasuminen ikääntyneen asumisen kontekstina. Tapaustutkimus ikääntyneiden toimijuudesta sekä vallasta ja sosiaalisista suhteista. Acta Universitatis Lapponiensis 364. Rovaniemi: Lapin yliopisto.

Salminen, Stela \& Andreou, Elena \& Holma, Juha \& Pekkonen, Mika \& Mäkikangas, Anne (2017) Narratives of burnout and recovery from an agency perspective: A two-year longitudinal study. Burnout Research 7, 1-9. https://doi. org/10.1016/j.burn.2017.08.001

Schmid, Hans (2014) Plural self-awareness. Phenomenology and the cognitive sciences 13,7-24.https://doi.org/10.1007/ s11097-013-9317-z

Schmid, Hans (2008) Plural action. Philosophy of the Social Sciences 38 (1), 25-54. https://doi. org/10.1177/0048393107310877

Seppänen-Järvelä, Riitta \& Syrjä, Vesa \& Juvonen-Posti, Pirjo \& Pesonen, Sanna \& Laaksonen, Maire \& Tuusa, Matti \& Savinainen, Minna \& Henriksson, Mik- ko (2015) Yhteistoimintaa ja yksilöllisiä valintoja kuntoutumisen polulla. Kelan työhönkuntoutuksen kehittämishankkeen tapaustutkimus. Sosiaali- ja terveysturvan tutkimuksia 141. Helsinki: Kela. http://hdl.handle.net/10138/158749 Luettu 17.6.2019.

STM (2015) Monialainen kuntoutus. Tilannekatsaus. Helsinki: STM. http://urn. fi/URN:ISBN:978-952-00-3509-9 Luettu 17.6.2019.

Tuusa, Matti \& Seppänen-Järvelä, Riitta \& Henriksson, Mikko \& Juvonen-Posti, Pirjo \& Pesonen, Sanna \& Syrjä, Vesa \& Savinainen, Minna (2018) Yhteistoiminta ja toimijuus kuntoutumista edistävinä vaikutusmekanismeina. Teoksessa Jari Lindh \& Kristiina Härkäpää \& Kaisa Kostamo-Pääkkö (toim.) Sosiaalinen kuntoutuksessa. Rovaniemi: Lapin yliopisto, 125-148.

Väyrynen, Sanna \& Lindh, Jari (2013) Yhteistoimijuuden rajakohteet päihde- ja mielenterveyskuntoutuksessa. Teoksessa Merja Laitinen \& Asta Niskala (toim.) Asiakkaat toimijoina sosiaalityössä. Tampere:Vastapaino, 405-426.

Åkerblad, Leena \& Haapakoski, Kaisa \& Tolvanen, Asko \& Mäntysaari, Mikko \& Ylistö, Sami \& Kannasoja, Sirpa (2018) Henkilökeskeisyyden ehdot. Kelan ammatillisen kuntoutusselvityksen arviointi. Sosiaali- ja terveysturvan tutkimuksia 154. Helsinki: Kela. http://urn.fi/ URN:NBN:fi-fe2018113049563 Luettu 6.8.2020. 